\title{
Sociological Study of the African Diaspora
}

\author{
By Jualynne E. Dodson ${ }^{*}$
}

There is an abundant amount of contemporary literature that discusses the idea of "diaspora» but such discussions usually are lodged within political and economic realities confronted by any migrating national and/or ethnic groupings. There also is literature that uses the language of diaspora and explores particular populations as examples of the phenomenon. However, there is much less literature that rigorously explores the definition of diaspora and how it does or does not differ from the idea of migration. Similarly, little if any literature examines theoretical propositions concerning the African Diaspora as put forth by sociologist Ruth Simms Hamilton. This paper engages Hamilton's four theoretical propositions, emphasing characteristics of the African Diaspora as a distinct global phenomenon and putting forth a useful typology. The hope is that such a systematic discussion can benefit the discipline of sociology given that the plethora of usages of diaspora language has almost rendered it ineffective as a concept for thorough academic explorations.

\section{Introduction}

I begin by giving thanks to all those who've gone before and made it possible for me to be at this time and place. I wish to thank, as well, all those involved in organizing this annual conference. I have been following these proceedings for some time but this is the first occasion wherein I could participate. Thank you! I also deeply appreciate members of the African Atlantic Research Team and express my gratitude to each of them for their time, energy, and support in all of my activities.

Today I wish to share clarifications and recommendations about propositional statements for studying the African Diaspora as putforth by sociologist Ruth Simms Hamilton. I base my support of Hamilton's proposition on the understanding that common ancestorial heritage, coupled with shared historical conditions and situations during most of the last five hunderd years, have helped form significant components of African descendants' identity throughout the globe, no matter their current geographic or national locations. I chose to focus on clarifications of the African Diaspora because I'm certain the discipline of sociology can benefit from Ruth Hamilton's clear theoretical thinking and that researchers can help improve the propositions.

*Professor, Department of Sociology, Director, African Atlantic Research Team, Michigan State University, USA. 
The paper identifies Hamilton's four propositions and explores characteristics that represent the generalized realities of African descendants as a distinct, global, social formation that differs from other diasporic populations. I give attention to her conception of the African Diaspora as product of a global collection of social forces, factors, and history in order to bring attention to her theoretical ideas for studying the phenomenon. I equally posit that Hamilton's ideas need more conceptual and research attention, especially by sociologists.

\section{Rationale}

In recent years, there has been a great volume and variety of use of the language of diaspora. Consider for example, that as of May 2013 some 42,597 Journal Storage (JSTOR) citations were noted to have used the term. The variety in use of the idea is equally numerous (Armstrong, 1976; Baumann, 2000; Carter, 2005). Such volume and variety of discourse tends to render the concept almost meaningless as a foundation for rigorous theoretical thinking and research exploration. As one author proclaims, "the abundant use went hand in hand with the term's semantic dissolution" (Baumann, 2000: 314 my emphasis).

Companion to this overabundance, is a general assumption that any transnational migration by any group, particularly large numbers of persons from an historical national base, equals a diaspora. I disagree! Such a broad and inclusive denotation in the process of conceptual framing of this particular human phenomenon thwarts our ability for clarity and thoroughness in theorizing or research. I contend that as sociologists we need to give stronger attention to the definition of diaspora as a separate concept, specifically to the definition of the African Diaspora, and to become especially conscientious in using both concepts. It is true that every diaspora involves transnational migration, but not all transnational migrations equal a diaspora. Nowhere is this made clearer than in the case of the global African phenomenon. Even as academic arenas are clear that our contemporary globalized world has materialized into current manifestations of expeditious advances in wireless and digital technology that facilitates rapid global communication by large numbers of people, they often forget that the same globalization was initiated some five centuries ago and that the involuntary disbursement of enslaved Africans was the catapult for the phenomenon.

\section{Generalized Diaspora}

While Ruth Hamilton's propositions for studying the African Diaspora are specific to those descendants and that phenomenon, her articulations sit squarely within existing literature concerning theoretical understandings about the general diaspora concept. This is true even as John Armstrong applied the concept "to any ethnic collectivity which lacks a territorial base within a given 
polity" (1976:393 quoted in Baumann, 2000: 313). William Safran also devoted early consideration to diaspora but, unlike Armstrong, he asserts that the global disbursal and importation of Africans and their descendants does not belong within conceptualizations of diaspora, at least not within his ideas about the circumstance (1991: 84, 90). Safran was incorrect of course and fortunately, sociologist Robin Cohen's full-length discussion in Global Diasporas Second Edition (2008) serves to correct most of Safran's earlier limitations.

Cohen argues that diaspora studies have gone through four phases; pre1980s' classical phase, the 1980s to the mid-1990s phase, the mid-1990s phase, and the turn to the 21 century forward as phase four (1-2). He then proceeds to attach these chronological and rather arbitrary time demarcations for studying diaspora to nine common features of the phenomenon from which he derives his five "ideal types" of diaspora (15-19). In a bit of what I call intellectual 'slight of hand,' Cohen vaguely combines the four phases with labels of ideal types and divides his remaining seven book chapters accordingly. For my consideration of the African Diaspora, Cohen's generalized discussion of common features, and his descriptive categories, positions the African Diaspora as a first such phenomenon of modern times, though he does not articulate it as this.

Robin Cohen's delineation of common features associated with diaspora, and his proposition of "ideal types," are important conceptual tools for use in systematic theorizing and research about diaspora, no matter the geographic location. Similarly, Cohen discusses concrete examples of several cultural communities, within their appropriate categories and features, to explore how they do or do not adhere to the specifications (Chapters 2-7). These rather more expansive yet specific considerations that include the African Diaspora, overlap with Ruth Hamilton's ideas about African descendants' expression of this particular type of human movement throughout the globe.

\section{Theoretical Considerations}

African Diaspora Visible: The general idea of diaspora, or the massive involuntary and semi-involuntary transnational movement of a cultural people from their lands of origin, is not new to academic or colloquial discourse (Anonymous, 1885; Levitt, 2003). However, the use of diaspora as related to African descendants" "routes of passage" does not enter academic circles until the October 1965 International Congress of African Historians held in Dar es Salaam, Tanzania (Shepperson, 1993: 41). This gathering led to the thematic incorporation of the African Diaspora into the United Nations' Educational, Scientific and Cultural Organization's multivolume General History of Africa (Ogot, 1992 and 1999; Harris, 1993:4).

Ruth Simms Hamilton was aware of the developing deliberations regarding the African Diaspora and regularly used the Kiswahili word of "maafa" in reference to the global phenomenon. The African continental synonym describes the idea of "a major event or even a series of events that 
cause great suffering, misfortune, upheaval, or trauma" for a human cultural community; a disruption that becomes part of the community's historical memory (Hamilton 2007:4). The/A maafa becomes a community's definitive socio-historical marker, an identifier constructed within their interactions of historical progress, a socio-historical marker that is placed as a component of their construction of distinct cultural expression, to become part of their collective sense of self. ${ }^{1}$

From the 1980s until her tragic death in 2003, Ruth Simms Hamilton and the historian Joseph E. Harris conversed and exchanged ideas about their mutual explorations of the African Diaspora. Harris was examining a multiplicity of historical details related to centuries of exorbitant deaths, excruciating suffering, outrageous tribulations, normative upheavals, and traumatic living experienced by Africans and their descendants. The conditions existed in their continental lands of origins and in the experiences of being transported from their cultural homelands to locations throughout the globe, particularly to the Americas. Harris defined the African Diaspora in the following manner:

...the African Diaspora resulted from unique historical developments, namely, the global slave trades conducted for centuries primarily by Arabs and Europeans, and the Berlin Conference of 1884-85 that partitioned Africa and set boundaries that continue to divide ethnic groups and inspire irredentism (2007:86).

This definition is logical, historically accurate, theoretically sound, and positions the African phenomenon within the larger global context that constructed it as a social formation. Yet Harris' definition also separates the African Diaspora from activities, events, and results that belong to imposed transnational migrations of other human populations. For example, the African global phenomenon stands distinct from Chinese, Indian, Armenian, Greek, Palestinians, or other diaspora occurrences even as each adheres to the larger conceptual definition.

For some five centuries that are recognized as the initiation, formation and development of the modern period, the forced captivity, as well as transnational and global movement of massive numbers of Africans as human cargo occurred through international migratory streams of transportation and trade. This African Diaspora was directly linked to the construction of modernity and became the first such global phenomenon of that period of human growth and development. Over time, the streams of transit and trade became defined, redefined, and engrained as organized formal patterns of global and transnational movement. The international patterns included internal local, regional, and

\footnotetext{
${ }^{1}$ Dr. Hamilton also shared the word and idea during a seminar discussion. She credits her former graduate student, Maria Pease for introducing the word into the diaspora lexicon. Personal conversation between Ruth Simms Hamilton and the African Atlantic Research Team, Graduate Seminar on Women \& Religion in the African Atlantic. East Lansing, MI: Michigan State University, November 4, 2003.
} 
national routes and together the global and internal categories of movement were used repeatedly to transport cargo - human and others, to and from known centers of successful trade and economy (Wallerstein, 2011).

The dynamic internal -- regional and local patterns of movement, coupled with similarly vigorous yet formalized transnational global migratory streams in which they functioned, caused social and political shifts among indigenous and imported population groups in new and old locations throughout the world (Harris 1982:36). As the involuntary transportation of captive Africans was outlawed late in the $19^{\text {th }}$ century, and European powers divided the African continent into colonies for their imperial economic benefit, the global system of transportation, trade, and transnational migration continued. The earlier involuntary out-migration of Africans from their continental cultural homes already had launched a series of socio-political and economic activities that established the shifted Africans and their descendants into post-colonial, postenslavement patterns that are our contemporary realities; the African Diaspora continues (Thompson 1987).

Definitional clarity delineated by historical continuity is but a single aspect in discerning concepts with theoretical implications. Ruth Hamilton was guided by Harris' historical articulations and centered her research on acquiring evidence that would help develop interlocking ideas for directing the theoretical study of the African Diaspora. She formed the African Diaspora Research Project at Michigan State University in 1987 and guided graduate students' research in identifying historical and empirical evidence (Dodson, 2010: 1-9). She was no longer interested in merely chronicling the dispersal of African people and/or describing their migration processes within episodic situations or time periods. Hamilton was concerned with enunciating a set of "sensitizing concepts that help make sense of empirical findings" (Wuthnow 2003: 22): she was interested in theory construction. She moved forward to articulate a typology, a set of theoretical propositions that categorized social phenomena and are appropriate for studying the African Diaspora. The remainder of this paper will discuss Hamilton's four propositions and probe with three to four significant areas of expansions.

Propositions: Ruth Hamilton contends that beyond the descriptive nature of the definition of the African Diaspora, there are four circumscribing conditions that identify the global phenomenon. The conditions have evolved within and from the initiating, involuntary, and semi-involuntary processes imposed by external forces that, for more than five centuries, displaced massive numbers of captive Africans from their homelands. Though altered and adjusted to new times and global realities, those processes and patterns of movement continue as distinguishing and defining characteristics in the lives of Africans and their descendants, in all their geographic locations. In speaking about the defining characteristics, Hamilton states that Africans and their descendants throughout the globe consistently have been subjected to conditions of: 
- Migration and Geo-Social Displacement: The Circulatoriness Phenomenon,

- African Diaspora Connections: Myths and Realities of Homeland Relations,

- Power, Domination, Inequality: Structurations of Black Dispossession,

- Agents of Resistance: Diasporic Identities and Communities of Consciousness.

These are propositional statements based on years of historical and empirical research conducted in a variety of global locations: Costa Rica, Panama, Dominican Republic, India, Brazil, Mexico, Colombia, the United States, Canada, Germany, and many others. Time and space does not allow me to exam each of the propositions but for those who are interested, I refer you to Hamilton's Routes of Passages Rethinking the African Diaspora, Parts 1 \& 2, Volume 1 (2007).

\section{Recommendations for Expanding the Propositions}

Gender and Class: Ruth Hamilton's propositional linkage of oppression with race and racism does not exclude the compounded significance that gender and class distinctions impose with the racism experienced for individuals within the African Diaspora. As she says, "in addition to being the first modern diaspora, African peoples for the most part constitute an oppressed racialized class subject in a world context" (2007: 28). Hamilton makes an important point about the patterns of race, gender, and class discrimination intersecting to continue creating conditions of oppression, domination, and subordination for the majority of African descendants throughout the globe. However, this erudite sociologist gave insufficient attention to the intersectionality and it is on those overlapping relations that expansion of her propositional statements about the African Diaspora begs to be addressed. This is clearly an arena where the skills, expertise, and comprehensions of sociologists can make contributions.

Similarly, Ruth Hamilton did not explore the discriminatory impositions experienced by Black women just because theirs is the combined identity. Neither did she attend to the dissimilar but sometimes overlapping experiences of Black men whose imposed experiences differ but are for similar reasons of their identity. Hamilton also did not offer much explication about the class-like, often caste-like functioning racism has had on both groups. And I would be remiss not to acknowledge the need for the African Diaspora framework to engage the multi-layered issues associated with gender identity that goes beyond the socially constructed definitions about "woman and man." This arena that encompasses Lesbian, Bi-sexual, Gay, and Trans-gendered persons is currently under serious attention, nationally and internationally. These are the places where sociologist could bring important conceptual and research 
insights for expanding the theoretical significance of Hamilton's propositions for the African Diaspora.

Historical Divisions: Even as I subscribe to and conduct my work by way of Ruth Hamilton's typology, I would posit other corrective issues to her original thinking about the historical, ongoing, and social conditions of life for members of the African Diaspora. I would recommend an historical demarcation that incorporates socio-political changes that occurred in the $20^{\text {th }}$ century decades of the 1950s and 60s. This was the time period when many African colonies achieved independence from European control. The political changes modified the dynamics of characteristic experiences for members within the African Diaspora. Initially, dynamics within the phenomenon had been distinguished by involuntary transnational global migration of aggregated groups of Africans. After decades of the 1950s and 60s, transnational outmigration by way of the African continent was predominantly the movement of Nigerians, Ghanaians, Togolese, Malians, Sierra Leoneans, Senegalese, South Africans, and other nationals. Independence on the African continent began to re-characterize the transnational global migration as by national individuals.

In addition to individuals or small groups of individuals moving from specific continental nations ${ }^{1}$, transnational migration also was no longer an involuntary or forced dispersal of aggregate groups of Africans and their descendants. The movement of individuals was now semi-involuntary, "push and pull" phenomena associated with global economic, political, and/or environmental issues. For example, Africans were pushed from their countries by violent changes in home governments, depressed local and national economies, military campaigns that pitted one ethnic group against another, egregious natural disasters, and/or famine. The moving individuals also were pulled away from their national locations by more developed nations' changes in immigration policies, or multi-national businesses' advertised lures of economic opportunity in other locations. Often these pulling enticements work in tandem.

Equally significant is that global forces that continue to push and pull individual African nationals into migration patterns also affect African descendants located outside of the continent and who are already part of the African Diaspora. I propose that mechanisms that brought about contemporary - post 1960s out-migration of African nationals are the adapted yet continuing apparatus of well-established global forces and movement patterns begun some five hundred years earlier.

Contemporary changes in the dynamics of African nationals' transnational movement leads many researchers to assume that current migration, including related social phenomena, is not part of earlier patterns connected with the African Diaspora. Such assessments are inclined to be ahistorical and do not usually consider the fuller contextual circumstances that precede and give cause for contemporary transnational migration of African and African

\footnotetext{
${ }^{1} \mathrm{t}$ must be remembered and noted that European empires created geographic nations on the African continent. This did not mean that the new nations adhered to the geographic boundaries experienced by cultural populations that preceded the nations.
} 
descendants. Perhaps such ahistorical treatments of continental descendants' current movements are linked to political sentiments about and/or for a postracial world where global movement can allow individuals to attempt to avoid racialized social exclusions that regularly accompany the migrations (Dodson, 2011; Martinez 2012). In a similarly fashion, some researchers choose to consider African descendants' modern-day relocation and settlement as a new African Diaspora (Okpewho 2009; Zeleza 2010). My grounding in Ruth Hamilton's propositional typology, and evidence from my own studies within the African Diaspora, lead me to reject both types of episodic assessments.

Movement: An additional Hamilton characteristic of the African Diaspora is that its members are in "migration and geo-social displacement." Conceptually, this encompasses the reality that since their diaspora began some five centuries ago, the lives of African descendants have been in perpetual states of movement; local, regional, transnational and global relocations. Therefore, migration and geo-social displacement, "geo-circularity" is a characteristic (Dodson 2011), not merely a passing attribute. Currently we can attend national identity to those who emigrate from the African continent and other locations, but the very fact of their movement remains as part of the push and pull forces of global economic and political phenomena. The African Diaspora is characteristically about geo-circularity.

Equally important within the expansion of Hamilton's geo-circularity propositional statement is that the migratory routes of modern-day semiinvoluntary individual African descendants are the same movement patterns stimulated by economic, political, and social positioning of their predecessors and/or ancestors' earlier involuntary movements. The global social institutions that initiated, structured and pre-determined African descendants' routes have been changed, sustained and now guide contemporary movements. As might be expected, there are dynamic difference between earlier social structures and those of today's globalized world. If nothing else, previous trading in human and other goods and services was legal and relatively tied to national infrastructures. Current forces that re-activate older movement patterns can easily be transnational networks not linked to a specific set of national regulations. This suggests that sociologists and other researchers who examine recent trends in African and African descendants' global movement must assume a more long-term, longue durée approach to their investigations. This is consistent with Emile Durkheim (1982: 69, 134) and Jürgen Habermas' (1984: 107-08) understanding that every domain of human activity already contains processes that exist before we begin trying to understand them.

I also suggest that we continue to employ the conceptual framework of the African Diaspora to probe historical migration patterns. Historical investigations that employ the perspective have proven exceptionally enlightening, even to what we thought we knew about the global phenomenon (see Guridy 2010; Bryant et al 2012). Focused discussions of details about African descendants' geo-circularity as part of historical and contemporary patterns can further characterize their diaspora. 
Conditions: Another recommendation for expanding Ruth Hamilton's propositions goes specifically to her discussion of oppression, domination, and subordination as social conditions of inequality that circumscribe normative realities for African and African descendants (1970:24). She proposes that this 'inequality tripartite' characterizes life for members of the African Diaspora. It has been and is the particular circumscribing socio-political and economic conditions, albeit that other human groups often share the conditions. However, Hamilton's work only intimates the continued existence of inequality, which begs the expansion of the original proposition. I would suggest that there are pivotal questions evolving from the Hamilton proposition and that they revolve around the relative permanent nature of inequality and socio-political conditions of those members of the African Diaspora. For example, how is it that after some five centuries, and unlike generations of other migrating cultural groups, collectively and disproportionately African descendants continue to experience political, social and economic inequality, no matter their geographic location (Fierce, 2007; Solorzano, 2000)? How is it that after multiple generations' migration, resettlement, and laborious struggles to achieve successful social integration into new national societies, African and African descendants as a group continue to hold unequal socio-political location in their societies?

Of course, there are individuals, and small pockets of individuals whose lives do not overtly reflect oppressive socio-political domination and/or visible racial discrimination but this is generally not true for most African descendant persons. One would think that after some five centuries of struggle and accomplishments against racial oppression, domination, and subordination, the collective contemporary social position of African descendants would bear no resemblance to their past societal situations. This is not true for the majority of African and African descendants across the globe as disproportionately they $\boldsymbol{d o}$ not share in benefits derived from industrial and technological development, nor in profits from these products of modernity (transafrica.org/people-ofafrican-descent/, Accessed June 2013; www.unesco.org/shs/most accessed December 2013).

The complex and elaborate ideology of Euro-centric superiority, in all of its manifestations, has been transmitted hegemonically throughout the globe as racial hierarchy. It also has been internationally rationalized to ensure distribution of privilege, position, and resources to those phenotypically of white-skin European descent or to those who appear to be close to that icon. Most African descendants do not come close to the criteria. The reality of racism and racialization that affects them are intricate and multi-level complexities of social infrastructures inherited from earlier historical periods, and the inheritance continues to produce stratified realities for African descendants, as well as other people of color (Omni \& Winant, 1994; Winant, 2004; 2011; Martinez HoSang, 2012). 


\section{Conclusion}

I conclude this attenuated discussion of Ruth Simms Hamilton's typology for studying the African Diaspora, not because it is impossible to continue but because neither time nor space allow me to engage more encompassing clarifications. However, I reaffirm my original purpose in discussing Hamilton's work by stating that her propositions form a theoretical approach for critical examination of the African Diaspora as a significant global phenomenon. I am a sociologist partly because I believe our discipline can provide a bases for better understanding how humankind perpetuates its social orders. This includes providing insights to the continuation of patterned global phenomena of inequality. For the sake of all humankind, I propose that sociologists are particularly obliged to systematically engage the challenge of fuller comprehending the African Diaspora as an historic and contemporary global social formation.

\section{References}

Anonymous, 1885. The Holy Bible (London: Oxford at the University Press. Chronicles 36:5-21; 2 Kings 25:1-21; Jeremiah 29:10; Daniel 9:2.

Armstrong, J. 1976. "Mobilized and Proletarian Diasporas," American Political Science Review, 70 (2): 393-408.

Baumann, M. 2000. "Diaspora: Genealogies of Semantics and Transculturation Comparison," Numen, Vol. 47, 3: 313-337.

Bryant, S. K., R.S. O'Toole, and B. Vinson III. 2012. Africans to Spanish America: Expanding the Diaspora. Urbana, IL: University of Illinois Press.

Carter, S. 2005. "The geopolitics of diaspora," The Royal Geographical Society, Area, Vol. 37, No.1 March: 54-63.

Clifford, J. 1994. "Diasporas," Cultural Anthropology, Vol. 9, No. 3, pp 302-328.

Cohen, R. 2008. Global Diasporas: An Introduction, second edition. New York: Routledge.

Dodson, J. E. 2011. "African Diasporal Studies and Religion." OJO The Journal of Trans-Atlantic Studies 1(1). editor, 2010. Ruth Simms Hamilton Fellowship Awards' Symposium: Commemorating the $20^{\text {th }}$ Anniversary of "Toward a Paradigm for African Diaspora Studies," Occasional Papers. East Lansing, Michigan: African Atlantic Research Team.

Drake, S. C. 2005. Diaspora Studies and Pan-Africanism. Ann Arbor, MI ProQuest Information and Learning.

Durkheim, E. 1982. The Rules of Sociological Method, New York: The Free Press.

Fierce, M. 2007. "Two Academic Programs in the African Diaspora: Afro-Brazilian Studies and U.S. Africana Studies," Routes of Passage Rethinking the African Diaspora, Parts $1 \& 2$, Volume 1, R. S.

Guridy, F. A., 2010. Forging Diaspora: Afro-Cubans and African Americans in a World of Empire and Jim Crow. Chapel Hill, NC: University of North Carolina Press.

Habermas, J. 1984. The Theory of Communicative Action, Vol. 1. Boston: Beacon Press.

Hamilton, R. S. editor, 1990. Creating A Paradigm And Research Agenda For 
Comparative Studies Of The Worldwide Dispersion of African Peoples. East Lansing: Michigan State University Press, pgs. 105-118.. editor, 2007. Routes of Passage Rethinking the African Diaspora, Parts 1 \& 2, Volume 1. East Lansing, MI: Michigan State University Press.

Hanchard, M. G., 2004. "Black Transnationalism, Africana Studies, and the $21^{\text {st }}$ Century," Journal of Black Studies, Vol. 35, No. 2, 139-153.

Hannaford, I. 1996. Race: The History of an Idea in the West. Washington, D.C.: Woodrow Wilson Center Press.

Harris, J. 1982. Global Dimensions of the African Diaspora Second Edition. Washington, D.C.: Howard University Press.

2007. "Historicizing the African Diaspora," Routes of Passage Rethinking the African Diaspora, R. Hamilton editor, East Lansing, MI: Michigan State University Press, 85-91.

Levitt, P. 2003. "You know, Abraham was Really the First Immigrant: Religion and Transnational Migration." The International Migration Review; Fall 2003: 37, 3.

Martinez HoSang, D., O. LaBennett, \& L. Pulido, 2012. Racial Formation in the Twenty-First Century, Berkeley, California: University of California Press.

Ogot, B.A. editor 1992 and 1999. General History of Africa. Berkeley, California: University of California Press.

Okpewho, I. and N. Nzegwu Editors. 2009. The New African Diaspora. Bloomington, IN: Indiana University Press.

Omni, M. and H. Winant 1994. Racial Formation in the United States: From the 1960s to the 1990s. New York: Routledge.

Patterson, T. R. and R.D.G. Kelley 2000. "Unfinished Migrations: Reflections on the African Diaspora and the Making of the Modern World" in African Studies Review 43, no. 1, 11-46.

Safran, W. 1991. "Diasproas in Modern Societies: Myths of Homeland and Return," Diaspora, Vol. 1, No. 1:83-99.

Solorzano, D., M. Ceja, and T. Yosso 2000. "Critical Race Theory, Racial Micro-aggressions and Campus Racial Climate: The Experiences of African American College Students" in The Journal of Negro Education, Vol. 69, No. 1/2, Winter-Spring, pgs. 60-73.

Thompson, V. B. 1987. The Making of the African Diaspora in the Americas 14411900. New York: Longman Inc.

Wallerstein, I. 2011. The Second Era of Great Expansion of the Capitalist WorldEconomy, Berkeley, California: University of California Press.

Winant, H. 1994. Racial Conditions: Politics, Theory, Comparisons. Minneapolis: University of Minnesota Press.

2004. New Politics of Race: Globalism, Difference, Justice. Minneapolis: University of Minnesota Press.

Wuthnow, R. 2003. "Studying Religion, Making It Sociological," Handbook of the Sociology of Religion, M. Dillon editor. Cambridge, UK: Cambridge University Press, pg. 16-44.

Zeleza, P. T. 2010. "African Diasporas: Toward Global History”, African Studies Review, volume 52, Number 1, April, pp. 1-19. 
